\title{
WIWISEKCJA ROZPADU CHIŃSKO-RADZIECKIEGO SOJUSZU
}

\author{
Lorentz M. Lüthi, Chiny-ZSRR. Zimna wojna \\ $w$ świecie komunistycznym, przeł. J. Pawłow- \\ ski, K. Urban-Pawłowska, Wydawnictwo Aka- \\ demickie DIALOG, Warszawa 2011, ss. 365.
}

Przystępując do pracy nad studium rozłamu chińsko-radzieckiego, Lorenz M. Lüthi był doskonale świadomy bogactwa literatury poświęconej tej tematyce. Jednocześnie jednak zdawał sobie sprawę, że opierając się na selektywnie dobranych źródłach, pozostawia ona wiele przestrzeni na różnego rodzaju spekulacje i domysły. Przyczyną tego stanu rzeczy były zamknięte dotąd na głucho i pilnie strzeżone archiwa, kryjące materiały źródłowe. Tymczasem przedstawienie rzetelnego obrazu stosunków chińsko-radzieckich, skutków ujawniających się w nich napięć oraz roli, jaką odgrywały w tym procesie czynniki, takie jak: ideologia, czynniki wewnętrzne czy osobowości przywódców - wymagało skrupulatnego przestudiowania całych kilometrów materiałów zgromadzonych w archiwach nie tylko głównych bohaterów dramatu, ale też innych państw obozu socjalistycznego oraz ich ideologicznych przeciwników. To do niedawna niewykonalne zadanie stało się nagle możliwe pod warunkiem gotowości do podjęcia benedyktyńskiej pracy. Rozpad Związku Radzieckiego i demokratyczne przemiany w Europie Środkowej i Wschodniej sprawiły bowiem, że badacze uzyskali dostęp do wielu opatrzonych wcześniej klauzulą „tajne” dokumentów. Również w otwierających się powoli od początku lat 80 . XX w. Chinach opublikowano już niemało źródeł - w tym sporo wiarygodnych - dotyczących zwłaszcza lat 50. i 60 ubiegłego wieku. Udostępniono tam także część archiwów i chociaż Centralne Archiwum Komunistycznej 
Partii Chin pozostaje wciąż pilnie strzeżonym skarbcem wiedzy, autorowi udało się dotrzeć do wielu ciekawych źródeł w archiwum prowincji Jiangxi, mających odniesienie do całego kraju.

To właśnie źródła są bodaj najmocniejszą stroną tej niezwykłej książki. Ich opisowi autor poświęcił dodatkowy, końcowy esej. Pisze w nim, że dotarł do materiałów archiwalnych zgromadzonych w Chinach, byłym ZSRR, Polsce, byłej NRD, w Czechach, na Węgrzech, w Bułgarii, we Włoszech i w Stanach Zjednoczonych. Tysiące przypisów bibliograficznych są dowodem tytanicznej pracy autora i mogą stanowić niezrównaną wręcz pomoc w dalszych badaniach. Profesor Jan Rowiński, z którego ekspercką wiedzą należy się liczyć, uznał tę pozycję za najpełniejszą historię przebiegu rozłamu chińsko-radzieckiego, jaka się dotychczas ukazała w literaturze światowej. Można zatem z pełnym przekonaniem stwierdzić, że Lorenz M. Lüthi stworzył dzieło, które przecierając ścieżki i prezentując tę tematykę z perspektywy faktograficznej, stanie się w literaturze przedmiotu pozycją klasyczną.

Odpowiedź na pytanie o sens zajmowania się tym wycinkiem historii jest tak oczywista, że wydaje się wręcz truizmem. Znaczenie nabrzmiewającego przez lata konfliktu dwóch gigantów świata komunistycznego nie ustępuje w niczym wadze innych ważnych wydarzeń okresu zimnej wojny, takich jak: powstanie muru berlińskiego, kryzys kubański, druga wojna wietnamska czy zbliżenie chińsko-amerykańskie, łącząc się zresztą z nimi ściśle. Autor wnikliwie analizuje rozpad stosunków chińsko-radzieckich. Nie ogranicza się jednak do zdania raportu z przebiegu owej ,zimnej wojny w świecie komunistycznym” z perspektywy Pekinu i Moskwy. Kreśli bogate tło relacji chińsko-radzieckich, przedstawia zawiłości polityki wewnętrznej głównych aktorów - zwłaszcza ChRL - oraz prezentuje wszystkie najważniejsze wydarzenia i posunięcia z dziedziny polityki zagranicznej, odgrywające rolę w przebiegu sporu.

Szukając odpowiedzi na pytanie o podłoże i przyczyny sporu, autor wskazuje na ,żywotną rolę ideologii”. Dwaj gorliwi wyznawcy marksizmu-leninizmu różnili się bowiem zarówno co do wizji wspólnej polityki socjalistycznego bloku, jak i metod budowy socjalistycznego społeczeństwa. Warto przy tym pamiętać, że stojący w obliczu konfliktów w kierownictwie, a nieznoszący jakiejkolwiek krytyki chiński wódz Mao Zedong wykorzystywał napięcia w stosunkach z ZSRR do własnych celów politycznych, przyczyniając się do zaognienia sporu. Wychodząc z dobrze potem uzasadnionej tezy, że większość pozostałych czynników konfliktu chińsko-radzieckiego miała źródło w sporze ideologicznym lub ustępowała mu pod względem znaczenia, autor wskazuje, że pierwsza odsłona tego dramatu miała miejsce już w końcu 1955 r. To właśnie wtedy, zgodnie z tzw. koncepcją ,,skokowego rozwoju", która miała dowieść tezy Mao Zedonga, że Chińczycy zbudują komunizm szybciej i lepiej niż ich „starsi radzieccy bracia”, Chiny wkroczyły na 
ścieżkę skompromitowanej już wcześniejszej strategii stalinowskiej - industrializacji kraju w drodze przyspieszonej pierwotnej akumulacji, przede wszystkim kosztem wsi. Znalazło to wyraz w szaleństwie Wielkiego Skoku i wznoszeniu Trzech Czerwonych Sztandarów (1958-1960), co pociągnęło za sobą co najmniej 20-25 milionów ofiar (głównie z głodu i niedożywienia) i cofnęło gospodarkę kraju do poziomu z 1952 r. Ostateczne rozmiary katastrofalnych skutków tego szaleństwa dotąd wymykają się szacunkom historyków ${ }^{1}$.

Drugim analizowanym przez Lorenza M. Lüthiego czynnikiem chińsko-radzieckiego konfliktu ideologicznego jest destalinizacja zainicjowana wygłoszonym na XX Zjeździe KPZR tajnym referatem Chruszczowa. Przy tej okazji autor stawia pytanie, co sprawiło, że o ile większość krajów obozu realnego socjalizmu oraz partii komunistycznych starała się wykorzystać postalinowską odwilż do zdobycia większej autonomii, rządzona przez Mao Zedonga ChRL (i Albania Envera Hodży) starła się z ZSRR, broniąc ideologicznego radykalizmu. Badając dostępne źródła, Lüthi dochodzi do wniosku, że to wewnętrzna sytuacja w Chinach sprawiła, że zarówno 1956, jak i 1957 r. upłynęły pod znakiem zaostrzającej się różnicy poglądów Mao i Chruszczowa na temat oceny teoretycznych i praktycznych dokonań Stalina.

Trzeci element ideologicznego sporu między Pekinem a Moskwą autor dostrzega w metodach walki z imperializmem. Na podstawie zgromadzonych źródeł doszedł on do wniosku, że zapoczątkowana przez Chruszczowa w 1956 r. polityka pokojowego współistnienia ze Stanami Zjednoczonymi (z polemiką wokół destalinizacji na pierwszym planie) $\mathrm{w}$ drugiej połowie lat 60. przesłoniła wszystkie inne aspekty stosunków chińsko-radzieckich, stając się - w oczach Chińczyków (czytaj: Mao) - prawdziwą „kością niezgody”.

Pisząc o znaczeniu ideologii, L. M. Lüthi nie pomija bynajmniej innych ważnych elementów, osadza je jednak w doskonale zdefiniowanym kontekście ideologicznym, pozwalając zrozumieć mechanizmy podejmowania decyzji i działań, co można podsumować stwierdzeniem, że osią chińsko-radzieckiego rozłamu były ideologiczne różnice wokół kwestii ekonomicznych, jak też pewnych aspektów polityki zagranicznej (stosunek do USA, pokojowej koegzystencji itp.). Ciekawą perspektywę otwiera autor na podstawie tezy, że w czasie zimnej wojny mocarstwa manipulowały konfliktami zagranicznymi, by skuteczniej zmobilizować własnych obywateli do celów polityki wewnętrznej. Widząc jej potwierdzenie w przypadku

${ }^{1}$ Frank Dikötter, autor najwnikliwszej jak dotąd pracy nt. chińskiego głodu po Wielkim Skoku, opartej na nieznanych dotychczas chińskich materiałach archiwalnych, szacuje liczbę ofiar tych ideologicznych eksperymentów i szaleństw aż na $45 \mathrm{mln}$ osób. Podobną liczbę - ponad $43 \mathrm{mln}$ podaje Jasper Becker, autor innej monografii poświęconej Wielkiemu Skokowi. Zob.: Frank Dikötter, Mao's Great Famine, Walker \& Co., London 2010; Jasper Becker, Hungry Ghosts: Mao's Secret Famine, Free Press, New York 1996. 
wykorzystania drugiego kryzysu tajwańskiego do zdobycia poparcia dla polityki Wielkiego Skoku, L. M. Lüthi dostrzega też w działaniach Mao Zedonga realizację odwrotnej strategii, polegającej na manipulowaniu polityką wewnętrzną dla osiągnięcia określonych celów w polityce międzynarodowej. Przykładowo, próba stworzenia modelowego społeczeństwa komunistycznego miała posłużyć wzmocnieniu roszczeń Mao do zastąpienia ZSRR w roli przywódcy obozu socjalistycznego.

Poddając równie pieczołowitej analizie obie strony sporu, autor wielokrotnie powtarza, że stroną, która wykazywała większą aktywność w dążeniu do rozłamu byli Chińczycy, którzy, gdy konflikt już się pojawił, nie pominęli żadnej okazji, by go podsycić. Posłużyły temu celowi odpowiednio prezentowane pod kątem potrzeb własnej polityki relacje radziecko-amerykańskie, roszczenia terytorialne oraz incydenty w rodzaju uwag wygłoszonych przez pijanego ministra obrony ZSRR, marszałka Rodiona Malinowskiego (podczas odbywającego się w listopadzie 1964 r. przyjęcia z okazji wizyty premiera Zhou Enlaia w Moskwie oświadczył on: nie chcę, by żaden Mao czy Chruszczow blokowali nas ... my już pozbyliśmy się Chruszczowa, teraz wy powinniście pozbyć się Mao. Mimo zapewnień Breżniewa, że wypowiedź nie odzwierciedlała oficjalnego stanowiska Moskwy, chińska delegacja wystosowała ostry protest i opuściła przyjęcie, wykorzystując później incydent do formalnej odmowy jakiegokolwiek kompromisu ze stroną radziecką).

Jak pisze L. M. Lüthi we Wstępie: Małostkowość i przesada w polemikach chińsko-radzieckich i ich wplyw na politykę wewnętrzna i zagraniczna obu krajów, od Wielkiego Skoku do konfliktu w roku 1969, powoduje u każdego współczesnego obserwatora niedowierzanie. Opinia ta doskonale oddaje odczucia, jakie towarzyszą czytaniu tej fascynującej pracy. Skrupulatność autora w posługiwaniu się źródłami nie pozostawia jednak miejsca na żadne wątpliwości - tak wyglądały czynniki i mechanizmy podejmowania politycznych decyzji, które odbijały się na losie setek milionów ludzi. 